1993

\title{
Perspectives from the New Haven School
}

Lung-chu Chen

New York Law School, lungchu.chen@nyls.edu

Follow this and additional works at: http://digitalcommons.nyls.edu/fac_other_pubs

Part of the International Law Commons

\section{Recommended Citation}

American Society of International Law Proceedings, Vol. 87, pp. 407-410

This Article is brought to you for free and open access by the Faculty Scholarship at DigitalCommons@NYLS. It has been accepted for inclusion in Other Publications by an authorized administrator of DigitalCommons@NYLS. 
The IL student is entitled to emerge from the basic course with some understanding of the international legal process, in all its subtlety. As with domestic law, international law is subject, thanks in large part to institutional processes, to ever faster change and expansion into new areas. The substantive doctrine of today may be irrelevant tomorrow, and the international lawyer is best prepared if he or she understands the process of change. This is, after all, how most law schools approach the teaching of domestic law, and it may be the only viable approach IL teachers can take as substantive doctrine expands beyond the confines of a three-credit course.

This panel probably would not be necessary if, like our domestic brethren, we could count on our students picking up various insights from a variety of international law courses throughout the curriculum. We would not be concerned about bringing these insights into the basic IL courses if, in addition, students were enrolled in an IO or a real international legal process course. We could then afford to focus on substantive doctrine in the IL course while the "legislation"equivalent course would give them the "public choice"'-equivalent insights. Reality is different. Most of us teach in schools where there is no IO alternative course, and even in schools where there is, most students take only basic IL survey courses. Unless we incorporate organizational insights into these courses, then, we risk training our students for the international law of the past, not of the future.

\section{Perspectives from the New Haven School}

\section{By Lung-chu Chen*}

Today's panel has been asked to address the question of where international organization fits into a modern-day course on international law. The question is significant, particularly given developments in international relations theory in recent years.

Let me say at the outset: international organizations, both governmental and nongovernmental, are important categories of participants (actors) in the world constitutive process of authoritative decision, that is, the international legal system. Although nation-states remain the principal participants in the present decentralized international legal system, international organizations have played increasingly important roles in response to the functional needs and imperatives of global interpendencies.

Additionally, international governmental organizations such as the United Nations and related specialized agencies have provided many of the transnational structures of authority and arenas of interaction that facilitate interstate interaction and decision making. Hence, a modern-day course on international law must give adequate attention to the roles played and functions performed by international organizations.

International legal scholars and international relations theorists have been somewhat estranged for some time. However, the study of international law and modern international relations theory, namely regime theory, might benefit from their closer cooperation and integration.

International regimes theory emerged in the 1980 s, focusing on normative orders called "international regimes." "Regimes," as defined by Stephen Krasner, are sets of "implicit or explicit principles, norms, rules, and decision-making proce-

*The New York Law School. 
dures around which actors' expectations converge in a given area of international relations." 1 Regime theory, as expounded by many other writers with varying emphases, is an analytical tool that attempts to explain the choices states make in a decentralized international system. The theory uses modes of analysis characteristic of rational choice theory, including game theory and economics.

Regime theorists tend to shift focus from the international system as a whole to interactions in particular issue areas, recognizing that the structure of interactions may differ from one issue area to another. Thus, they talk about different international regimes, such as security regimes, international economic regimes, the international monetary regime, international trade regimes, the international regime for oil, human rights regimes, the global environmental regime, the regime of world information and communication, the Polar regimes, and so forth.

Regime theorists consider such structural attributes as the availability of information and the transaction costs of state interactions in determining whether states can effectively achieve their goals in particular issue areas. Seeking institutionalization of long-term cooperation, they emphasize international rules, procedure and institutions. Although regime theory has seen considerable development in recent years, it is not without detractors and is subject to some controversy.

Turning now to "The New Haven School," it was created and developed by Myres McDougal, Harold Lasswell and their associates, and its name was coined by our distinguished panel Chair, Professor Falk. The New Haven School provides a configurative approach to international legal studies that seeks to transcend the narrow positivism of the traditional, rules-oriented approach to international law. Building on the insights of American legalism, the New Haven School has moved beyond the vista of legal realism.

This policy-oriented approach is contextual, problem-solving, and multimethod. It is contextual in the sense of viewing the role of law in society dynamically, by relating it to relevant social, community and decisional contexts and variables. It is problem-solving in the sense of recognizing the intrinsic function of law as an instrument of policy for promoting a preferred social order and of providing an effective tool to optimize the function of law. It is multi-method in the sense of seeking to mobilize and integrate intellectual skills to facilitate effective problem solving toward the establishment of a more peaceful, abundant and just world-namely, a world community of human dignity.

The New Haven School sees international law as a continuing process of authoritative decision through which members of the world community identify, clarify and secure their common interests. International law serves not only as a limit on effective power, but also as a creative tool for promoting both order and other values. The New Haven approach seeks not only to describe the process of authoritative decision making, but also to provide a constructive jurisprudence to facilitate problem-solving in a decentralized world.

The main features of the New Haven School include: (1) the establishment of an observational standpoint; (2) the formulation of problems; (3) the delimitation of the focus of inquiry; (4) the explicit postulation of public-order goals; and (5) the performance of intellectual skills. Let us briefly examine each feature.

The establishment of observational standpoint involves self-screening. An observer's standpoint needs to be kept as distinct as humanly possible from the

\footnotetext{
'Stephen D. Krasner, Structural Causes and Regime Consequences: Regimes as Intervening Variables, 36 INT'L ORG. 185, 186 (1982).
} 
process under scrutiny, so that appropriate criteria for appraisal can be developed. The appropriate observational standpoint, as stressed by the New Haven School, is that of citizens of the world community who are identified with the future of humankind as a whole rather than with the primacy of any particular group.

Problems are formulated in terms of a set of value categories and a social process model, giving balanced emphasis to both values and institutions. Eight values-respect, power, enlightment, well-being, wealth, skill, affection and rectitude-are employed to facilitate studies that transcend cultural and community boundaries. (The aggregate of these values may be described as security.) Institutional practices are described by reference to the participants, perspectives, situations, base values, strategies, outcomes and effects in any particular context of interaction. Problems arise when there are disparities between demanded values and their achievement in the community process.

In delimiting the focus of inquiry, the New Haven School seeks to be both comprehensive and selective. It establishes a focus on authoritative decisions in their context, placing equal emphasis on the conception of law to be deployed and the larger context to be studied. The focus is on the entire flow of authoritative decision making. Law is perceived not as mere rules, but as a continuous process of authoritative decision by which members of the community clarify and secure common interests. With balanced emphasis on both authority and control, law relates not only to what people say, but also to what they do-not only to perspectives, but also to operations.

Authority refers to the normative expectations of community members about who is to make what decisions, in what structures, by what procedures, and in accordance with what criteria. Control refers to effective participation in the choices that are put into community practice. The conjunction of authority and control is the key to a viable concept of law: In the absence of decision characterized by authority, international law is an expression of naked power; and when control does not accompany decision, international law may become mere illusion and mockery.

In an interdependent world, the degree of effectiveness of international law does not depend merely on the social and decision processes within any single territorial community. It depends also on the operation of such processes within a whole hierarchy of interpenetrating communities, from local or national to regional and global. It requires a firm grasp of the dynamic interplay between transnational and national processes of decision and their reciprocal impacts.

Recognizing that problem solving cannot be value free, the New Haven School explicitly postulates public-order goals in terms of human dignity, embracing both minimum world order and optimum world order. Minimum world order is used in the sense of minimization of unauthorized coercion and violence, that is, maintenance of international peace and security. Optimum world order is used in the sense of the widest possible shaping and sharing of all values-in other words, justice, human rights, development, environmental protection and so on.

Finally, for the New Haven School, a whole set of intellectual tasks must be performed to achieve rational decisions in furtherance of postulated public-order goals. These tasks include the clarification of goals, the description of past trends in decisions, the analysis of factors affecting decisions, the projection of probable future developments, and the invention and evaluation of policy alternatives.

These intellectual tasks are distinct, yet interrelated. Each affects and is affected by the others. It is crucial that all tasks be performed systematically and contextually in relation to each specific problem. 
In light of the foregoing, how do regime theory and the New Haven School relate to each other? In a fundamental sense, regime theory is significantly different from the New Haven School. There are many ways, however, in which the two approaches are similar, and ways in which they may complement each other.

The most obvious difference between the two approaches is that regime theory is a theory of international relations, while the New Haven School is a theory about international law. Regime theory represents an attempt to describe and explain interactions among states at the international level based on a set of assumptions about state behavior. The New Haven School, on the other hand, is a policy-oriented, problem-solving approach to international law that defines international law as an ongoing process of authoritative decision in which decisionmakers at all levels of community shape and formulate policy.

Regime theory abstracts internal processes of decision making and relies on assumptions about an "ideal" state actor in order to simplify analysis; the New Haven School, on the other hand, keeps the analysis open-ended and is highly contextual.

In a variety of ways, however, regime theory and the New Haven School are more similar to each other than either is to the traditional, rule-centered approach to international law. Both consider the context in which decisions are made, and recognize how context shapes and conditions decision making. Neither sees international rules, procedures and institutions as immutable and autonomous, capable of self-application. Instead, both recognize norms and institutions to be the outcome of a continuous process of authoritative decision making as actors attempt to achieve public-order goals.

The New Haven School and regime theory can enrich and reinforce each other, drawing upon each other's insights. Properly adapted and applied, they could help foster the conjunction of authority and control and strike a proper balance between realism and idealism in furtherance of common interest and cooperation.

Together, they could contribute mightily to bridging the gap between international legal scholars and international relations theorists. Students of international law will benefit from each of these approaches as they seek to understand the complex, interdependent, but still decentralized system of international decision making.

I have experimented with and used quite effectively, I have thought, a method for teaching international law that incorporates the comprehensive approach just outlined.

International law, it may be recalled, is a continuing process of authoritative decision by which members of the world community clarify and secure their common interests. The common interests are composed of both minimum world order and optimum world order. The goal of minimum world order seeks to minimize unauthorized coercion and violence to achieve international peace and security. Those subjects relating to use of force, self-defense, community enforcement action, economic sanctions, dispute resolution and so on will naturally fall within the domain of study. The goal of optimum world order is to achieve the widest possible shaping and sharing of all values. This can be expressed in terms of human rights, development, trade and investment, the global environment, resource management and so on. The study of the Constitution and foreign affairs will underscore the interpenetrating dynamics of transnational and national processes of decision making. These matters should also be touched upon in a contemporary international law course. Because of time constraints, they can be touched upon with varying degrees of attention in a basic, introductory course. This can be 